\title{
La palabra concedida. Discursos y actitudes "transgresoras" femeninas en la antigua Roma monárquica y republicana
}

\author{
The Given Words. "Transgresive" Female Speeches and Behavior in the Ancient \\ Monarchical and Republican Rome
}

\author{
Pedro David Conesa Navarro* \\ Universidad de Murcia/ Università degli Studi di Roma-Tor Vergata \\ pedrodavid.conesa@um.es \\ Recibido el 20 de febrero de 2018 \\ Aceptado el 21 de julio de 2020 \\ BIBLID [1134-6396(2020)27:2; 437-462] \\ http://dx.doi.org/10.30827/arenal.v27i2.7048
}

\section{RESUMEN}

En este trabajo pretendemos analizar y describir algunas figuras femeninas emblemáticas de la antigua Roma. Tradicionalmente, las mujeres han sido silenciadas y relegadas por los autores clásicos. Aquellas que sobresalieron del resto se debió a que actuaron de manera contraria a sus roles de género. Sin embargo, algunas de sus participaciones en el ámbito público estuvieron justificadas, pues ante situaciones excepcionales y de gran transcendencia para el Estado tenían que abandonar el hogar. En este trabajo no solo repasaremos algunos acontecimientos significativos relacionados con mujeres de la época monárquica y republicana, sino que intentaremos analizar la transcendencia social que tuvieron sus actuaciones.

Palabras clave: Actitudes transgresoras. Discursos femeninos. Mujeres sabinas. Lucrecia. Virginia. Veturia. Lex Oppia. Hortensia.

\section{ABSTRACT}

In this paper we intend to analyse and describe different emblematic women of Ancient Rome. Traditionally, the women have been silenced and relegated by the classics authors. Those who stand out from the rest are those who were able to because they acted from opposite ways of their gender

* Este trabajo ha sido posible gracias a la concesión de un Contrato Predoctoral FPI de la Fundación Séneca. Agencia Territorial de Ciencia y Tecnología de la Región de Murcia (19829/ FPI/15). Miembro del Grupo de Investigación ARHIS (Arqueología Histórica y Patrimonio del Mediterráneo Occidental) (E041-08) de la Universidad de Murcia, cuyo investigador principal es el Dr. José Miguel Noguera Celdrán. Miembro del Grupo de Investigación Deméter. Maternidad, Género y Familia de la Universidad de Oviedo, cuya investigadora principal es la Dra. Rosa María Cid López. 
roles. Nevertheless, some of their public acts were justified because when there were exceptional situations; besides of the great importance for the State, they must leave their home. In this work we will not only rework the different acts related with women of the Monarchy and Republic period, but we will also analyse the social importance of their acts.

Keywords: Transgresive behavior. Female speeches. Sabine women. Lucretia. Verginia. Veturia. Lex Oppia. Hortensia.

\section{SUMARIO}

1.- Introducción. 2.-Los relatos "míticos" de las sabinas, Lucrecia, Virginia y Veturia: prototipos femeninos de la Antigua Roma. 3.-El relato femenino en los espacios masculinos: El levantamiento contra la lex Oppia y el discurso de Hortensia. 3.1.-La derogación de la lex Oppia: el triunfo de la unión femenina en la Antigua Roma. 3.2.-El discurso de Hortensia. Un unicum en la Roma Antigua. 4.-Conclusiones. 5.-Bibliografía.

\section{1.--Introducción}

Un tema sumamente estudiado fue la posición subordinada a la que estuvieron sometidas las mujeres en la sociedad romana ${ }^{1}$. Una etapa en la que el patriarcado imperaba y la voz femenina estaba excluida de los ambientes públicos y, por supuesto, de los círculos y órganos de poder. En el reciente libro de la profesora Mary Beard, Women \&Power. A Manifesto ${ }^{2}$, pese a que es innegable su formación y dedicación al mundo clásico, se realiza un discurso diacrónico de la situación femenina a lo largo de la Historia, mostrando especial interés por Occidente. Comenzó con un destacado pasaje de la Odisea en el que Telémaco, hijo de Penélope y Ulises, a pesar de ser un adolescente, mostró sus dotes como nuevo jefe del oikós ante la ausencia de su padre. Concretamente, el relato se desarrolló cuando Penélope, tras abandonar sus aposentos, se acercó a un aedo que estaba cantando las penurias que atravesaban los griegos durante su regreso al hogar. La reina le sugirió que cambiara de temática, ya que no era de recibo debido a las circunstancias que estaba atravesando su marido. Telémaco, sin embargo, intervino y ordenó a su madre que callara y se dedicara a otras actividades como la rueca, el telar y la dirección de sus siervas, pues no le competía hablar a una mujer sobre cuestiones varoniles ${ }^{3}$.

1. Sobre historiografía de las mujeres en el mundo romano, cf. Cid López, 2006; Mirón Pérez, 2010; Cid López, 2010; Pedregal Rodríguez, 2011; Cid López, 2015; Conesa Navarro, 2016.

2. Beard, 2017. La traducción castellana ha sido publicada recientemente por la editorial Crítica. Cf. Beard, 2018.

3. Hom. Od., I, 325-364. 
El pasaje de la obra de Homero se considera como el primer testimonio escrito de la literatura occidental en el que un varón silencia a una mujer ${ }^{4}$. La determinación que mostró el hijo de Ulises en sus palabras ha sido interpretada por Felson$\mathrm{Rubi}^{5}$ como una de las características de la tosquedad juvenil. Sin embargo, tal y como indicó Reboreda Morillo, en este pasaje se pretendía reflejar la madurez adquirida por Telémaco al demostrar que podía hacerse responsable de su casa. Además, como jefe familiar supo reubicar a las mujeres en el lugar que le correspondían. Penélope acató la orden y no solo eso, sino que sintió admiración por la decisión que había tomado su hijo ${ }^{6}$. Tras esta narración, siguió exponiendo Beard diversos pasajes importantes de la literatura grecolatina, especialmente aquellos en los que las mujeres, aunque de manera tímida, fueron capaces de romper sus "silencios" y adentrarse en la esfera pública. Retomando dicha idea, en este trabajo pretendemos mostrar una serie de ejemplos, algunos de ellos descritos por la profesora de clásicas de la Universidad de Cambridge, en los que las mujeres fueron capaces de tener cierto protagonismo. Para ello, no solo intentaremos detenernos en las diferentes historias en sí, sino explicar el trasfondo social y político que tuvieron sus acciones.

A lo largo de la Historia de Roma, de manera esporádica aparecieron ciertas mujeres que fueron descritas por diversos autores antiguos. El problema estriba en conocer la intencionalidad con la que estos narraron sus historias. Personajes emblemáticos como Lucrecia, Virginia o Veturia descritas por Tito Livio entre otros, fueron arquetipos de la perfecta matrona ${ }^{7}$. Atributos como esposa fiel y sensible, persona educada y culta, con altos conocimientos intelectuales, alta delicadeza, gran hermosura, decorosa y pía, fueron algunas de las cualidades atribuidas a las matronas romanas que correspondían en ocasiones más bien a personajes mitificados y ficticios ${ }^{8}$. Desde las dóciles y virtuosas Lucrecia y Virginia, pasando por la madre Veturia, se terminará con los ejemplos significativos de aquellas que se manifestaron a favor de la derogación de la lex Oppia y Hortensia, esta última destacada por ser la primera mujer que se atrevió a pronunciar un discurso en el foro. Estos relatos entrañan diversas dificultades. En primer lugar, no sabemos hasta qué punto son verídicos los acontecimientos que pretendemos analizar. Pertenecían a la tradición romana y en su mayoría debido a la lejanía en el tiempo, se fueron transmitiendo de forma oral hasta que diferentes autores clásicos decidieron ponerlos por escrito. En segundo lugar, todas ellas fueron grandes personajes pertenecientes a la alta sociedad del momento. Por tanto, la mayoría de las mujeres de la sociedad romana, así como las que disponían de escasos

4. Beard, 2017: 3-4.

5. Felson-Rubi, 1994: 71.

6. Hom. Od., I, 360-364; Reboreda Morillo, 2009: 59-60.

7. Girod, 2017: 40.

8. Ferrer Alcantud, 2014: 6-7. 
recursos o las esclavas, no estaban representadas en estos relatos. Éstas, por el contrario, en ningún momento tuvieron los instrumentos necesarios para que sus voces fueran tenidas en cuenta en los círculos de poder. No obstante, no deja de ser sorprendente que algunas de ellas tuvieran la capacidad para influir, así como el hecho de que los escritores del momento decidieran otorgarles un espacio en sus obras, ya fuera para reprobarlas o para ensalzarlas. Con ello se demuestra que no fueron objetos pasivos, sino que defendieron sus intereses cuando vieron peligrar su situación con el único propósito de restaurar y mantener la idea de Estado que habían heredado de sus ancestros.

2.-Los relatos "míticos" de las sabinas, Lucrecia, Virginia y Veturia: prototipos femeninos de la Antigua Roma

Tito Livio, en su obra $A b$ urbe condita, se preocupó por narrar los acontecimientos que marcaron la Historia de Roma. En el prefacio comentó que, a pesar de que muchos pasajes, en especial los más antiguos, han quedado oscurecidos con el paso del tiempo y son difíciles de interpretar, se disponía a narrar aquellos considerados gloriosos ${ }^{9}$. Consciente de que era complejo diferenciar entre lo real y lo mitológico en épocas tan remotas, pues las noticias reunidas estaban repletas de fabulaciones poéticas, no se resistió a contar los orígenes de Roma ${ }^{10}$. Efectivamente, los relatos relacionados con la fundación de la ciudad tendrían como protagonistas a dos gemelos amamantados por una loba y criados por un pastor de nombre Fausto ${ }^{11}$. Cuando crecieron la situación se volvió insostenible y uno de ellos, Rómulo, terminó asesinando a su hermano y fundando la ciudad el 21 de abril de 753 a.C.

El nuevo rey se encontró con el inconveniente de que no había mujeres e intentaron establecer alianzas con los sabinos. Ante la negativa de éstos, pues no conocían los orígenes ni los antepasados de los recién llegados, Rómulo planeó un secuestro y convocó unos juegos solemnes en honor a Neptuno, los llamados Consualia $^{12}$. Desde el principio, la violencia fue una constante en los primeros

9. Liv., I, 1-6. Esta misma crítica de acontecimientos oscuros en los orígenes de Roma también se expresan en Plutarco. Plut. Rom., XIV, 2.

10. Liv., Pr., 6-7.

11. Sobre la cuestión de los gemelos Rómulo y Remo cf. Molas Font, 2009: 138-150. Además de ideas sugerentes, aporta las principales fuentes clásicas sobre el tema.

12. Liv., I, 9, 1-7. Según el relato proporcionado por Dionisio, los matrimonios mixtos que propuso en principio Rómulo era una medida encaminada a establecer nuevas alianzas. Al pensar que no se unirían a él mediante pactos fue entonces cuando planeó raptar a las doncellas. Tras pedir la aprobación de Senado, anunció la celebración a las fiestas en honor a Neptuno y convocó a todos los pueblos a que asistieran. Dion. Hal. Ant. Rom., II, 30, 1-4. De manera más poética, Ovidio narra los acontecimientos de similares características. Cf. Ov. Fast., III, 167-200. 
relatos de la Urbs, violencia que también afectó a las mujeres. Pese a que resulta complejo establecer su veracidad, la historiografía defiende que el rapto de las sabinas encierra el pensamiento patriarcal que imperó en el mundo romano. Con motivo de las celebraciones programadas por Rómulo, llegó gente de todas partes a Roma. Tito Livio señaló que los sabinos trajeron consigo a sus mujeres e hijos (cum liberis ac coniugibus uenit) ${ }^{13}$. Cuando todos estaban pendientes de los espectáculos, los jóvenes romanos se lanzaron a capturar a las doncellas ${ }^{14}$ (iuuentus romana ad rapiendas uirgines discurrit) sin llevar un orden, aunque sí que tenían especial interés por las más bellas ${ }^{15}$.

Los enfrentamientos entre ambos bandos eran inevitables. Además, las mujeres raptadas se comprometieron con sus nuevos maridos y les dieron descendencia. Tras diversas contiendas, las mujeres sabinas, conscientes de que ellas eran las culpables de la guerra (quarum ex iniuria bellum ortum erat), se presentaron en el lugar de la batalla con los cabellos sueltos, las vestiduras rasgadas y en actitud suplicante. Les imploraban que no cometiesen la impiedad que suponía mancharse con la sangre de un suegro o de un yerno ${ }^{16}$. Una de ellas, Hersilia, realizó un compungido discurso ${ }^{17}$ que resumía los anhelos del resto y provocó una gran conmoción en los ejércitos. De hecho, la alianza y la paz entre ambos bandos se consiguieron gracias a la maniobra de estas mujeres, cuya repercusión más inmediata fue la fusión de ambos pueblos ${ }^{18}$. Plutarco también expuso de manera más extendida que Livio el alegato de Hersila con idénticos parámetros ${ }^{19}$. La diferencia entre ambos radica en que en el relato del autor de Queronea las mujeres no se consideraban culpables

13. Liv., I, 9, 7-9. Dionisio también habla de una gran muchedumbre acompañada por sus hijos y esposas, Dion. Hal. Ant. Rom., II, 30, 4.

14. Según las estimaciones propuestas por Dionisio de Halircarnaso eran seiscientas ochenta y tres que las distribuyó a un número igual de jóvenes de Roma. Dion. Hal. Ant. Rom., II, 30, 6.

15. Liv., I, 10-12. Parecido es el discurso dado por Dionisio. Dion. Hal. Ant. Rom., II, 30, 4-5.

16. Liv., I, 13, 1-3.

17. Liv., I, 13, 3-4: "Si adfinitatis inter uos, si conubii piget, in nos vertite iras; nos causa belli, nos uolnerum ac caedium uiris ac parentibus sumus; melius peribimus quam sine alteris uestrum uiduae aut orbae niuemus". Dionisio también alude a dicho discurso. Dion. Hal. Ant. Rom., II, 45, 6.

18. Liv., I, 13, 3-5.

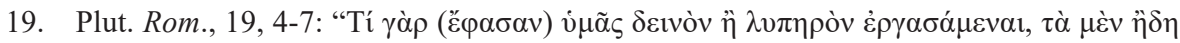

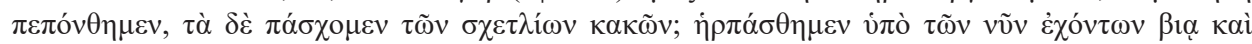

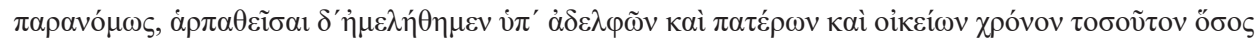

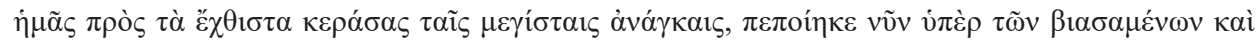

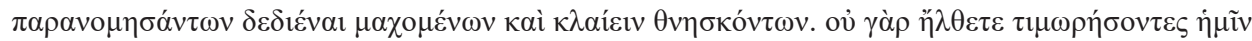

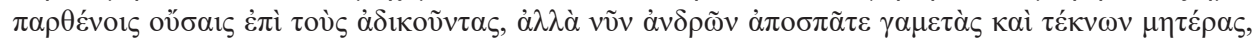

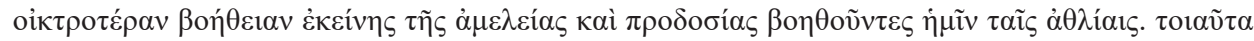

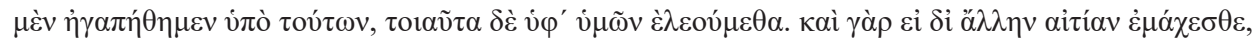

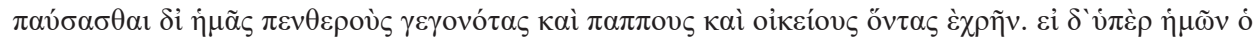

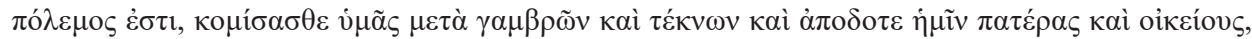

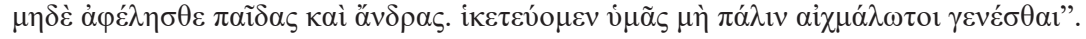


de lo sucedido, pues fueron raptadas por la fuerza y en contra de los preceptos marcados por las leyes. Sin embargo, de ser causantes del conflicto exhortaban a que se reconciliaran los varones y que ellas no fueran consideradas prisioneras de guerra. Tanto Dionisio como Ovidio mencionaron que antes de que las mujeres llegaran a la contienda, premeditaron una estrategia ${ }^{20}$. Decidieron llevar los cabellos sueltos, vestidas con luto y con sus hijos en sus regazos. La escena es desgarradora, pues se pusieron de rodillas y los niños lloraban y tendían sus brazos hacia sus abuelos en actitud suplicante ${ }^{21}$.

Aunque parece incuestionable que el anterior pasaje fue una historia fantasiosa, su ejemplo fue el primero que sirvió para forjar el modelo maternal romano. Pese a que fueron secuestradas, separadas y ultrajadas, se mostraron fieles a sus $\operatorname{maridos}^{22}$. Lo más sorprende del testimonio es que ellas se autoinculparon de la guerra ${ }^{23}$. Hersilia sería recordada por ser la mediadora que posibilitó la paz entre ambos bandos, además de por haber realizado un importante servicio a la comunidad. De hecho, en memoria suya y del resto de sabinas, se constituyó una fiesta femenina, las Matronalia ${ }^{24}$, celebrada cada 1 de marzo, mes dedicado a la guerra. Algo sorprendente, pues durante ese período se ensalzaban valores masculinos relacionados con el arte de la batalla ${ }^{25}$. Además, también se celebraba en ese período el año nuevo y se honraba a la diosa de los partos, Iuno Lucina, que era una exaltación de la maternidad y un recuerdo al matrimonio instituido por Rómulo $^{26}$. La imagen que se diseñó de Hersilia, tal y como indicó Cid López, poco tenía que ver con la domesticidad propia de las mujeres romanas; pues ella lideró a un grupo nutrido de matronas para mediar en el conflicto armado que se estaba desarrollando en Roma. Su vida, plagada de episodios violentos, está colmada de referencias sucedidas fuera de la $d o m u s^{27}$.

Los episodios de Lucrecia y Virginia, que desencadenaron acontecimientos de gran transcendencia, se caracterizaron por tener como protagonistas a mujeres individuales a diferencia del relato anterior. No actuaron junto con otras y su

20. Dion Hal. Ant. Rom., II, 45, 1-2. Este autor no especifica el lugar, pero sí que menciona que Hersalia fue la que propuso llevar a cabo una solución. Por su parte, Ovidio menciona que el lugar de reunión fue el templo de Juno. Ov. Fast., III, 205-206: Conveniunt nuptae dictam Iunonis in aedem quas inter mea sic est nurus ausa loqui.

21. Ov. Fast., III, 205-232. Dionisio no habla del llanto de los niños, pero sí enumera la escena de igual forma que Ovidio. Dion. Hal. Ant. Rom., II, 45, 4-6.

22. Girod, 2017, p. 31.

23. Dionisio también dice que ellas fueron las culpables del enfrentamiento. Cf. Dion. Hal. Ant. Rom., II, 45, 1.

24. Para explicar el origen de esta fiesta, Ovidio habla del rapto de las sabinas en sus Fastos. Ov. Fast., III, 167-258.

25. Cid López, 2007: 368

26. Cid López, 2009: 167-168; Ibid., 2011: 62.

27. Cid López, 2017: 211-212. 
importancia radica porque tuvieron un espíritu y una actitud diferente a lo que se presuponía que debían tener. La muerte de Lucrecia desencadenó la desaparición de la Monarquía y la instauración de la República en el 509 a.C., mientras que el segundo marcó el final del primer decenvirato ${ }^{28}$. Ambas encarnaban la uirtus, fides, honestas y pudor que toda matrona romana debía perseguir ${ }^{29}$. Sobre la primera de ellas, el relato más completo fue el ofrecido por Tito Livio. El pasaje pretendía mostrar el ideal de esposa fiel y valedora del honor familiar. De Luce consideró que se daban características suficientes para poner en entredicho la veracidad de los datos ${ }^{30}$.

Los combatientes que lucharon en Ardea, una noche en la que estaban bebiendo en la tienda de Sexto Tarquinio, decidieron apostar cuál de ellos tenía la mejor esposa. Parece que la conversación fue acalorada a consecuencia de los efectos del vino, o así lo dejaron entrever Tito Livio (incaluerant uino) y Ovidio ${ }^{31}$. Fue el propio Tarquinio Colatino quien planteó que, para salir de dudas, lo mejor sería comprobarlo por ellos mismos ${ }^{32}$. Cuando ya estaba oscureciendo llegaron a Colacia y encontraron a Lucrecia trabajando la lana y no como a las nueras del rey, que fueron sorprendidas en un suntuoso banquete. Todos se percataron de que la vencedora fue Lucrecia. Sexto Tarquinio sintió un deseo incontrolable por poseerla no solo por su belleza, sino también por su recato ${ }^{33}$. Sus intenciones no cesaban, así que Sexto decidió regresar a casa de Tarquinio Colatino. Fue recibido con agrado y terminó adentrándose en los aposentos de la doncella y confesarle su amor. Ella se resistió a los propósitos del invitado y éste como respuesta la amenazó de muerte. También haría lo propio con un esclavo, al cual degollaría y lo colocaría junto a su cadáver para que su honor fuera ultrajado ${ }^{34}$. Fue precisamente el miedo a perder la honra familiar lo que hizo que no opusiera resistencia. Hay que tener presente que

28. Fuentes Moreno, 2009: 88.

29. Baeza Angulo y Buono, 2013a: 264; Ibid., 2013b: 33; Conesa Navarro y González Fernández, 2016: 592-593.

30. De Luce, 2005: 2: "In a very real sense the story of Lucretia is emblematic of Roman mythology in that it includes features found both in legend and in stories which we would call myths".

31. Ov. Fast., II, 731-732: quisque suam laudat: studiis certamina crescunt, et fervet multo linguaque corque mero.

32. Liv., I, 57, 6-8. La versión ofrecida por Dionisio de Halicarnaso, pues la visita de Sexto Tarquinio a Colacia no se debió a una apuesta entre los varones para saber cuál de ellos tenía la mejor esposa, sino que fue a la ciudad de Lucio Tarquino porque fue enviado por su padre, el rey Tarquinio el Soberbio y se enamoró de Lucrecia por el trato recibido, por su belleza y su prudencia a la que trató de seducir. Cf. Dion. Hal. Ant. Rom., IV, 64, 2-5. Ovidio por su parte sigue el esquema planteado por Livio. Cf. Ov. Fast., II, 733-738.

33. Liv., I, 57, 8-11; Ov. Fast., II, 739-781.

34. Liv., I, 58, 1-5. Concretamente, las palabras que le dice Sexto Tarquinio a Lucrecia fueron: "Tace, Lucretia" inquit; "Sex. Tarquinius sum; ferrum in manu est; moriere, si emiseris vocem. Este pasaje también se repite en Dionisio, cf. Dion. Hal. Ant. Rom., IV, 64, 5; 65, 1-4. 
el concepto de honor en esta época tan arcaica era muy elevado, pues la situación terrible y personal a la que se enfrentó Lucrecia estaba al margen de la violación sufrida $^{35}$. Los efectos negativos que acarreaba su violación para su estirpe eran mucho mayores que los daños físicos que pudiera sufrir. Abatida tras lo sucedido, hace llamar a su padre y a su marido que no se encontraban con ella en ese momento. Una vez llegados a Colacia, se la encontraron sentada en sus aposentos y llorando. Tras relatar lo sucedido ${ }^{36}$ instó a sus familiares a que vengaran su muerte:

Vosotros veréis - responde - cuál es su merecido, por mi parte, aunque me absuelvo de culpa, no me eximo de castigo; en adelante ninguna mujer deshonrada tomará a Lucrecia como ejemplo para seguir con vida. (Liv. I, 58, 11-12, traducción de José Antonio Villar Vidal, 1990) ${ }^{37}$.

Después de pronunciar dichas palabras se clavó un cuchillo en el corazón que guardaba entre sus ropas y finalmente concluye la escena con los gritos de sus familiares ${ }^{38}$. Bruto fue el encargado de extraer el arma del cuerpo sin vida de la joven y quien prometió venganza y eliminar a la estirpe de Tarquinio el Soberbio ${ }^{39}$. Es significativa la afirmación ofrecida por Ovidio, al calificar a la joven como una matrona de espíritu varonil que trajo consigo muchas lágrimas a consecuencia de su muerte (Fertur in exsequias animi matrona uirilis et secum lacrimas inuidiamque trahit $)^{40}$.

La otra gran mujer descrita por Livio en esta etapa temprana de la Historia de Roma fue Virginia. A diferencia de Lucrecia, que tomó la iniciativa de poner fin a su vida, esta doncella, prometida de Lucio Icilio, fue asesinada por su padre. Sin embargo, pese a las diferencias existentes entre ambas, fue el propio Livio quien presentó a esta última como un nuevo ejemplo de crimen pasional, poniéndola en relación con la mujer de Colatino ${ }^{41}$. A ello podríamos añadir que las similitudes entre Lucrecia y Virginia no solo se encuentran por tener grandes consecuencias políticas, sino también por el cambio social que se experimentó tras la muerte

35. Bravo Bosch, 2017: 71.

36. Liv., I, 58, 5-10. La versión ofrecida por Dionisio de Halicarnaso difiere sensiblemente de la de Livio, pues fue ella la que fue en busca de sus parientes. Cf. Dion. Hal. Ant. Rom., IV, 66, 1-2.

37. "Vos" inquit "uideritis quid illi debeatur: ego me etsi peccato absoluo, supplicio non libero; nec ulla deinde impudica Lucretiae exemplo uiuet”. Dionisio de Halicarnaso también dijo que Lucrecia pide que se vengue su muerte. Cf. Dion. Hal. Ant. Rom., IV, 66, 2-3.

38. Liv., I, 58, 11-12. Ovidio describe la escena de manera parecida a Livio. Cf. Ov., Fast., II, 782-836. Dionisio menciona que las que lloraron fueron las mujeres, mientras el padre besaba y abrazaba el cuerpo de su hija agonizante, pensando que se iba a recuperar. El resto del relato reproduce más o menos lo dicho por Livio. Dion. Hal. Ant. Rom., IV, 67, 1-2.

39. Liv., I, 59, 1-2; Ovid, Fast., II, 837-846.

40. Ov., Fast., II, 847-848.

41. Liv., III, 44, 1. 
de ambas. En ellas se reunían las características fundamentales que las jóvenes, fieles a las tradiciones romanas y al honor familiar, debían perseguir. Aunque actualmente pueda parecer desmesurado que un padre tomara la determinación de asesinar a su hija, en el pensamiento antiguo fue un acto lícito e incluso necesario si la situación lo requería. Sabemos que en los primeros momentos de la Urbs el paterfamilias tenía un poder ilimitado. Entre sus diferentes prerrogativas contaba con el derecho sobre la vida y muerte de los individuos dependientes de su gens, el ius uitae et necis ${ }^{42}$.

Apio Claudio se enamoró perdidamente de la plebeya Virginia e intentó seducirla a través de regalos y promesas. Viendo que no lo conseguía, decidió contratar a Marco Claudio para que la reclamara. Así que, un día que se dirigía la joven hacia el foro, el enviado de Claudio llevó a cabo su encargo. Mientras que Virginia se mostró sorprendida por lo que estaba sucediendo, su nodriza gritó y pidió socorro, lo que permitió que una gran muchedumbre fuera a socorrerlas. Para intentar solucionar la situación, Marco argumentó que la joven era hija de una de las esclavas de Claudio y citó a Virginia a que compareciera ante la justicia ${ }^{43}$. Hasta aquí podríamos establecer la primera parte de la narración, después comienza el alegato de Apio ante los tribunales diciendo que había pruebas suficientes que incluso el propio Virginio no podría negar, que demostraban que la joven era de su propiedad. Señaló que la muchacha nació en el seno de su hogar y que fue raptada y trasladada a casa de Virginio, quien la reconocería después como hija suya. En el juicio había partidarios del padre de Virginia que no estaban dispuestos a que se dudara de su paternidad. El proceso fue aplazado hasta que este último llegó, pues no se encontraba en la ciudad. Se presentaron tanto Icilio $^{44}$, el prometido de Virginia, como Publio Numitorio ${ }^{45}$, un pariente suyo, cuyos esfuerzos resultaron en vano ${ }^{46}$.

La tercera y última parte del relato podríamos situarla en el momento en el que Virginio regresó a Roma. Toda la población se encontraba congregada en el foro para ver cómo evolucionaban los acontecimientos. Este último, vestido de luto, llegó con su hija y unas matronas ${ }^{47}$. Livio describió la escena con gran dramatismo, queriéndonos poner en antecedente el desenlace de la historia. Tras los diversos alegatos e intervenciones, Virginio no encontró otra solución y se llevó a su hija

42. Dixon, 1992: 117-118; Cortes, 2004: 89; López Huguet, 2006: 197; Conesa Navarro y González Fernández, 2015: 90-91.

43. Liv., III, 44, $2-9$.

44. Livio reproduce un virulento discurso de Icilio con palabras amenazante a consecuencia de que su prometida había quedado apresada. Cf. Liv., III, 45, 6-11.

45. Según la versión ofrecida por Livio en este relato, era el abuelo de la joven. Sin embargo, más adelante (Liv., III, 54, 11) nos menciona que era su tío materno.

46. Liv., III, 44, 9-12; 45, 1-11; 46, 1-10.

47. Liv., III, 47, 1. 
a un lugar apartado en las cercanías del templo de Cloacia. Tras coger un cuchillo de carnicero le indicó que la única libertad que le podía ofrecer era matarla. Acto seguido le atravesó el pecho con el arma que tenía en sus manos (pectus deinde puellae transfigit ${ }^{48}$. Después de asesinarla, Virginio se dirigió a Apio culpándole de lo sucedido y maldiciéndole tanto a él como a su estirpe ${ }^{49}$. El triunviro ordenó apresar al padre de la joven fallecida, pero finalmente éste consiguió escapar con la ayuda de algunos de sus partidarios ${ }^{50}$. Es sorprendente que cuando Icilio y Numitorio levantaron el cuerpo sin vida de Virginia para que todo el pueblo congregado fuera testigo de lo sucedido, Livio sentenció mencionando que todo había ocurrido por dos aspectos fundamentales: por la belleza de la muchacha (puellae infelicem forman) y por la ineludible obligación a la que se vio abocado su progenitor (necessitatem patris deplorant) ${ }^{51}$.

Lo interesante de Virginia y Lucrecia fue que, pese a tener un destino fatal, fueron consideradas como víctimas "vencedoras". Permanecieron fieles a las costumbres romanas y su espíritu no se doblegó ${ }^{52}$. No sabemos si Virginia ofreció resistencia o si intentó salvar su vida; aunque debido a que tanto ella como su padre iban vestidos de luto para el juicio, podemos presuponer que era consciente de lo que iba a suceder y acató la decisión paterna. Por el contrario, sí que conocemos las palabras que pronunció Lucrecia antes de morir. Estamos, por tanto, ante dos mujeres con espíritu masculinizado. La subordinación y la incapacidad femenina a la hora de tomar decisiones o participar en las magistraturas venía amparada por principios biológicos y morales. Los varones, considerados perfectos, eran los únicos que tenían la uirtus, facultad que los hacía superiores ${ }^{53}$. Por tanto, era impensable para el pensamiento racional antiguo que las mujeres actuaran con tanta entereza como los ejemplos anteriores. Su extrañeza posibilitó su inserción en el relato histórico, pues no solo debían ser recordadas por el resto de las mujeres, sino por todos los ciudadanos, cuyos sacrificios se realizaron por el bienestar común. No sería hasta el pensamiento cristiano, como Agustín de Hipona entre otros, cuando fueron criticadas, especialmente Lucrecia, por no resignarse y optar por el suicidio cuando es Dios el único que podía poner fin a la vida humana ${ }^{54}$.

48. La frase pronunciada por Virginio a su hija ha sido recogida por el autor latino. Liv., III, 48, 5: "hoc te uno quo possum" ait, "modo, filia, in libertatem vindico".

49. Concretamente, la frase pronunciada por Virginio fue: Liv., III, 48, 5-6: “Appi, tuumque caput sanguine hoc consecro".

50. Liv., III, 48, 6-7.

51. Liv., III, 48, 7-8.

52. Chiusi, 2016: 594-595.

53. González Suarez, 1999: 205; Conesa Navarro y González Fernández, 2015: 102.

54. Ag. Ciu Dei, I, 19; Fuentes Moreno, 2009: 107; Gallego Franco, 2015: 320; Conesa Navarro y González Fernández, 2016: 595-560. 
El tercer y último relato legendario de la Historia de Tito Livio fue el relacionado con Coriolano y Veturia. A diferencia de las dos historias anteriores, el desenlace no tiene como resultado una muerte femenina, sino todo lo contrario. Gneo Marcio, que recibió el sobrenombre de Coriolano ${ }^{55}$, fue conocido por aliarse con los enemigos de Roma. Para ello nos tendríamos que retrotraer al siglo v a.C., cuando la plebe adquirió ciertos derechos a consecuencia de sus protestas en el monte Aventino. En un momento dado, vino trigo de Sicilia y Coriolano fue uno de los que intentó negociar su precio, encareciéndolo a menos que el poder senatorial fuera restablecido ${ }^{56}$. Las medidas propuestas fueron excesivas incluso para los propios senadores. El descontento de los plebeyos fue tal, que estuvieron a punto de tomar las armas ${ }^{57}$. El hijo de Veturia finalmente optó por aliarse con los

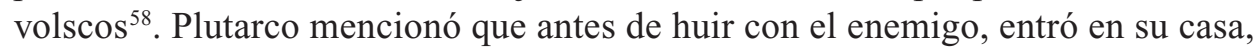
abrazó a su madre y esposa que se lamentaban con gemidos y gritos, y tras pedirles que no sufrieran, se marchó ${ }^{59}$. Dionisio de Halicarnaso recreó una escena parecida. Mientras que Veturia y Volumnia lloraban ante la marcha de Marcio Coriolano y en presencia también de sus hijos, éste no mostró ningún signo de tristeza ${ }^{60}$. Tras aliarse con los volscos, que le confiaron un ejército con el que obtuvo diferentes victorias contra los romanos, llegó a cercar la propia Roma provocando una gran angustia e inestabilidad ${ }^{61}$.

Tras la presión ejercida por la plebe para poner fin al enfrentamiento, el Senado envió una serie de embajadas a Marcio que no fueron escuchadas ${ }^{62}$. Fue entonces cuando las matronas acudieron a Veturia, madre de Coriolano, y a Volumnia, su esposa, para que intercedieran e intentaran resolver la situación ${ }^{63}$. Los

55. Liv., II, 33, 5-6; Dion. Hal. Ant. Rom., 6, 92-94.

56. Liv., II, 34, 7-12. El pasaje del trigo también lo recoge Plutarco. Cf. Plut. Cor., 16, 1.

57. Liv., II, 35, 1-4. Extenso es el fragmento aportado por Plutarco, que califica de demagogos y traidores a quienes accedían a las pretensiones de la plebe. Los tribunos a su vez contraatacaron incitando a la plebe a la rebelión. Plut. Cor., 16, 2-7; 17; 1-8.

58. Liv., II, 35, 6-7.

59. Todo el pasaje del exilio cf. Plut. Cor., 21, 1-6. Concretamente, cuando se dirige a su madre y esposa es Plut. Cor., 21, 3-4. Dionisio nos dice que Marcio Coriolano había sido acusado de tirano y que había sido condenado al destierro. Cf. Dion. Hal. Ant. Rom., VIII, 1, 2.

60. Dion Hal. Ant. Rom., VIII, 41, 2-3. Este hecho lo narra la propia madre de Coriolano, en la que también indica que cuando las encontró estaban sentadas, vestidas de luto y con harapos.

61. Redondo-Moyano, 2016: 335.

62. Liv., II, 39, 8-12; Plut. Cor. 31, 6-7; Dion Hal. Ant. Rom., VIII, 38, 1-3; Val. Max. V, $4,1$.

63. Liv., II, 40, 1. Es interesante que Livio sigue el relato diciendo que no se sabe si las matronas decidieron actuar por iniciativa propia o por un mandato oficial (Liv., II, 40, 1-2), lo que evidencia que muchas veces el Estado era el encargado de incitar a las mujeres a adentrarse en la esfera pública cuando era necesario. Valerio Máximo por su parte menciona que la determinación de ir a los campamentos enemigos fue de la propia Veturia. Cf. Val. Max., V, 4,1. Por su parte, Plutarco, cuando reproduce el alegato de Valeria especifica que las mujeres han ido por iniciativa propia. Cf. Plut. Cor., 33, 5. Lo mismo podríamos decir en Dionisio. Cf. Dion. Hal. Ant. Rom., VIII, 40, 2. Tanto 
relatos ofrecidos por Plutarco y Dionisio de Halicarnaso son más extensos. Narran que Valeria, mujer que gozaba de respeto y fama, fue la portavoz de todas para interceder por la situación ${ }^{64}$. Las palabras tuvieron contestación por la progenitora de Coriolano con un amplio discurso en el que los valores patrios estaban por encima de los familiares ${ }^{65}$. Convencieron a ambas a que fueran junto con los hijos de Marcio a los campamentos enemigos y que con sus lágrimas y lamentos consiguieran cambiar su opinión. Solo la presencia de Veturia hizo que el guerrero se sintiera conmovido y saliera al encuentro de su madre para abrazarla ${ }^{66}$. Plutarco mencionó que, antes de que ésta hablara, se produjo el añorado abrazo. Según Livio, Marcio fue informado de que su madre, esposa e hijos se aproximaban a los campamentos, mientras que Plutarco matizó que fue el propio Coriolano quien los vio acercarse ${ }^{67}$. Por el contrario, Livio propuso que antes del abrazo se produjo el discurso que supuestamente Veturia profirió ante su hijo. El fragmento está repleto de referencias patrióticas y de amor familiar ${ }^{68}$, con el que se pretendía demostrar que ir contra Roma suponía posicionarse frente al que hasta ahora había sido su Estado, además de un rechazo a su familia. Tras las palabras de su madre, Coriolano la abrazó al igual que a su mujer e hijos. Después alejó las legiones de las cercanías de la ciudad ${ }^{69}$. El desenlace descrito por Plutarco fue más extenso, tras las palabras de Veturia parece que su hijo le respondió y accedió a las peticiones

Livio, Dionisio de Halicarnaso como Valerio Máximo mencionan que la madre de Marcio Coriolano fue Veturia y Volumnia la esposa. Cf. Dion. Hal. Ant. Rom., VIII, 39, 4; 40, 1; Val. Max., V, 4, 1. Por el contrario, Plutarco menciona que Volumnia era la madre de Coriolano, mientras que Virgilia la esposa. Cf. Plut. Cor., 33, 4-5.

64. Plut. Cor. 33, 2-6; Dion. Hal. Ant. Rom. VIII, 40, 1-5. En Dionisio hay otro discurso previo de Valeria que corresponde cuando la joven exhortó al resto de matronas para ir a ver a Veturia y Volumnia. Cf. Dion. Hal. Ant. Rom., VIII, 39, 1-5.

65. Plut. Cor., 33, 7-10; Dion Hal. Ant. Rom., VIII, 41, 1-6; 42, 1-2. Dionisio prosigue diciendo que sus palabras conmocionaron a las mujeres cuyos lamentos se escuchaban por toda la ciudad y al final accedió a las pretensiones de las matronas. Dion. Hal. Ant. Rom., VIII, 43, 1-3.

66. Liv., II, 40, 2-5.

67. Plut. Cor., 34, 1-3.

68. Liv., II, 40, 5-9: "Sine, priusquam complexum accipio, sciam" inquit, "ad hostem an ad filium venerim, captiva materne in castris tuis sim. In hoc me longa vita et infelix senecta traxit ut exsulem te deinde hostem viderem? Potuisti populari hanc terram quae te genuit atque aluit? Non tibi, quamvis infesto animo et minaci perveneras, ingredienti fines ira cecidit? Non, cum in conspectu Roma fuit, succurrit: intra illa moenia domus ac penates mei sunt, mater coniunx liberique? Ergo ego nisi peperissem, Roma non oppugnaretur; nisi filium haberem, libera in libera patria mortua essem. Sed ego mihi miserius nihil iam pati nec tibi turpius usquam possum, nec ut sum miserrima, diu futura sum: de his videris, quos, si pergis, aut immatura mors aut longa servitus manet". El discurso en Plutarco, cf. Plut. Cor., 35, 2-9. Además, nos dice que tras sus palabras en un primero momento no tuvieron efecto y tuvo que intervenir de nuevo la madre de Coriolano. Cf. Plut. Cor., 36, 1-3. En Valerio Máximo es más escueto, cf. Val. Max., V, 4, 1.

69. Liv., II, 40, 10; Val Máx V, 4, 1. 
que venían reclamando las matronas ${ }^{70}$. Interesante al respecto fue la puntualización esbozada por Dionisio de Halicarnaso previo a que las mujeres fueran a los campamentos enemigos. Al parecer, una vez que tomaron la determinación de ir ellas, requirieron el beneplácito de los cónsules y estos convocaron al Senado y preguntaron si era oportuno que las mujeres fueran a entrevistarse con Marcio. Tras un debate en el que unos eran proclives y otros no, finalmente se consiguió la aprobación de la cámara ${ }^{71}$.

Encontramos de nuevo, tal y como ocurría con las sabinas, a mujeres que consiguieron paralizar una guerra tras organizarse. Se escenifica a grandes rasgos el mismo esquema: una mujer, Valeria, representa a todas las matronas e interviene para convencer a Veturia y Volumnia a que vayan a los campamentos de los volscos ${ }^{72}$. Sin embargo, hay ciertas divergencias. En este caso no fue la esposa la que intercedió, como lo ocurrido con Hersilia, sino la madre. Además, Veturia, a pesar de las referencias a los valores patrios empleados en su discurso, habló como ciudadana, anteponiendo las cuestiones particulares o familiares ${ }^{73}$. Con esta acción demostraba una madurez propia de su edad, cosa que Lucrecia y Virginia no contaban. Fue precisamente su oratoria lo que permitió que Coriolano terminara por arrepentirse. Por tanto, nos encontramos en este ejemplo con el triunfo de la auctoritas materna ${ }^{74}$. Tito Livio desarrolló el término agmen mulierum para referirse a las acciones protagonizadas por mujeres que se organizaban y trasgredían sus espacios domésticos con el fin de demandar actos que consideraban injustos. Fue precisamente la acción de estas mujeres ante Veturia la primera vez que aparece el vocablo tal y como recuerdaba Cid López ${ }^{75}$. Esta misma terminología fue empleada por historiador de Patavium para referirse a aquellas que se organizaron con el fin de conseguir el derrocamiento de la lex Oppia. Su significado, poliédrico, procede del contexto militar por la forma de organización del ejército castrense en columnas, así como por las unidades que operaban en el campo de batalla. De igual forma, la utilización de mulierum y no muliebris también tiene su razón de ser. Pues con el empleo de palabra en caso genitivo se pretendía mostrar elementos propios del comportamiento femenino como era la falta de autocontrol, la debilidad o el llanto ${ }^{76}$. Medidas que utilizaronutilizaron las mujeres para conseguir sus propósitos y no como los hombres, cuyas armas de actuación se fundamentaban en la guerra, la oratoria y la política.

\footnotetext{
70. Plut. Cor., 36, 4-8.

71. Dion. Hal. Ant. Rom. VIII, 43, 1-7.

72. Valentini, 2012: 53.

73. Dixon, 1992: 118.

74. Cid López, 2009: 169.

75. Liv., II, 40, 3; Cid López, 2017: 209.

76. Cid López, 2017: 209-211.
} 
3.-El relato femenino en los espacios masculinos: El levantamiento contra la lex Oppia y el discurso de Hortensia

3.1. - La derogación de la lex Oppia: el triunfo de la unión femenina en la Antigua Roma

En el año 215 a.C., durante el consulado de Tiberio Sempronio Graco y Quinto Fabio Máximo, se propuso una ley por el tribuno Gayo Opio conocida como la Lex Oppia sumptuaria. El objetivo fundamental consistió en gravar el lujo y la suntuosidad de las mujeres patricias, lujo considerado por los sectores más tradicionalistas como excesivo ${ }^{77}$. Esta ley fue derogada apenas dos décadas después a través de la lex Valeria Fundaria de 195 d.C. Pese a que el marco temporal parece estar bien delimitado, hubo voces que discreparon sobre su autenticidad ${ }^{78}$. $\mathrm{Al}$ ordo matronarum se ingresaba por nacimiento o matrimonio, compartía al igual que el sector senatorial con ciertos privilegios sociales que aseguraban su superioridad y servían para diferenciarse del resto. Uno de los distintivos era precisamente la vestimenta $^{79}$. Las matronas lucían stolae y uittae adornadas con púrpura que era lo equivalente al latus clauus y la toga viril ${ }^{80}$. Debido a que fueron mujeres de alta posición, su condición económica era desahogada, lo que les permitía además tener importantes sumas de dinero. En el fondo con sus prendas también estaban exhibiendo su rango aristocrático y el de toda su familia ${ }^{81}$. Esta imagen pública y privada se fosilizó especialmente a través de la retratística. Tanto en monumentos funerarios como en estatuas honoríficas, aparecen representadas con sus principales atributos $^{82}$. Por tanto, ya desde la República encontramos a través de la documentación epigráfica y literaria a mulieres que se adentraron en espacios públicos ${ }^{83}$.

Esta ley suntuaria afectaba de manera exclusiva a estas últimas. Las restricciones impuestas eran contra el lujo femenino, especialmente contra las prendas coloridas teñidas de púrpura ${ }^{84}$. También se prohibía tener o llevar más de media onza de oro, además de emplear un carro de dos caballos para desplazarse por la ciudad, o acercarse con él a la Urbs a una distancia inferior a mil pasos si no

77. Bauman, 1002: 31.

78. Sobre esta cuestión, cf. Casinos Mora, 2015: 225-227.

79. La vestimenta fue uno de los elementos definitorios de las sociedades clásicas y podríamos hacerlo extensible al resto de culturas y épocas. Tanto griegos como romanos y en diferentes soportes, epigráficos e incluso en narraciones literarias se observa la importancia del atuendo. Cf. Culham, 1986: 235-236.

80. Hemelrijk, 1999: 11.

81. Cid López, 2010: 136.

82. Oria Segura, 2016: 160.

83. Cenerini, 2014: 63; Manzo, 2016: 121.

84. Casinos Mora, 2015: 231. 
estaba justificada por cuestiones religiosas ${ }^{85}$. Se supone que las mujeres en época republicana, fieles a las costumbres romanas, tenían que demostrar austeridad y recato a la hora de vestir ${ }^{86}$. Por tanto, tal y como afirmó Berg, tras compararla con la lex Iulia del año 46 a.C., observamos que esta norma era también una forma de vigilarlas desde el plano moral ${ }^{87}$.

A los agravios materiales, se sumaron otros humanos debido a la cantidad de fallecidos en la contienda. La pobreza, el hambre y la escasez fueron efectos también del conflicto bélico. Los duelos y funerales constituyeron de los pocos momentos en los que podían mostrar a toda la sociedad su condición social. Debido a la cantidad de difuntos se marcaron los tiempos de duelo y se redujeron al mínimo las pompas fúnebres, a lo que habría que añadir que, si se prolongaban los lutos, terminarían suspendiéndose las ceremonias religiosas y por lo tanto no se obtendría la protección divina. Con esta ley se instaba delimitar la exhibición de las mujeres, además de sus pasiones ${ }^{88}$.

Las matronas se sintieron discriminadas y decidieron interceder para que se les respetara sus privilegios, para ello elevaron sus súplicas a los familiares femeninos de los triunviros, acciones que fracasaron, por lo que se vieron abocadas a asumir el espacio masculino, calificada esta acción por Pomeroy como la "primera manifestación femenina" 89 . Livio indicó que no solo protestaron las patricias de la Urbs, sino también algunas venidas de los centros rurales se sumaron a la causa. Les rogaban a cónsules y pretores y a otros magistrados que se anularan los contenidos de la ley ${ }^{90}$. Reclamaba que se restauraran sus privilegios, pues consideraban que la lex Oppia estaba caduca. Las tensiones que se sucedieron fueron intensas. La sociedad se mostró fraccionada entre aquellos que opinaban que no solo había que mantenerla, sino incluso endurecerla, como fue el caso de los tribunos Marco y Publio Junio Bruto ${ }^{91}$. Frente a otros que querían eliminarla, cuyos representantes fueron los tribunos de la plebe Fundanio y Lucio Valerio ${ }^{92}$. El Capitolio se encontraba abarrotado y toda la población comentaba el asunto ${ }^{93}$.

85. Liv., XXXIV, 1, 1-3; Zonar. 9, 17, 1-4; Val. Max., 9, 1, 3; Clemente, 1981: 5; López López, 1992: 319; Mastrorosa, 2006: 590-591. Livio emplea el verbo habere cuando hace referencia a la onza de oro, lo que se ha podido interpretar o bien que no "podían tener" o "llevar". Cf. Cantarella, 1991: 38. Entre otros, Culham fue partidario de pensar que lo que hacía referencia al verbo era a lo que les estaba permitido llevar a estas mujeres. Cf. Culham, 1982: 787 nota 7.

86. Nogales Basarrate, 2017: 52.

87. Berg, 2002: 43.

88. Cid López, 2010: 140

89. Pomeroy, 1987: 199. Esta afirmación la ofrecen otros investigadores como García Jurado, 2011: 172 .

90. Liv., XXXIV, 1, 5-7.

91. Liv., XXXIV, $1,4$.

92. Liv., XXXIV, 1, 2-3.

93. Liv., XXXIV, 1, 4-5. Bauman, 1992: 32; Ferrer Alcantud, 2012: 267. 
Livio desarrolló el alegato de Marco Porcio Catón ${ }^{94}$, uno de los oponentes a la derogación de la ley, cuyo contenido consta de las siguientes partes: En un primer momento, como preámbulo, se indica la situación a la que desembocó la inacción de los varones. Estos últimos no fueron capaces de controlar a sus mujeres por separado, lo que condicionó que todas ellas terminaran por unirse y provocaran una situación desastrosa y desordenada. Estas matronas fueron capaces de ocupar el espacio público, un ámbito reservado a los ilustres hombres de la Urbs. Por el contrario, estos se encontraban ahora subyugados y privados de libertad, vencidos, machacados y pisoteados por la insubordinación femenina ${ }^{95}$. Después se cambia de registro y tras presentar diferentes ejemplos de lo peligroso que resultaba que los varones fueran privados de libertad, Catón intentó persuadir a los magistrados con el fin de que reflexionaran y tuvieran en consideración la decisión tan importante que suponía su voto ${ }^{96}$.

A continuación, intentó explicar el origen de esta "consternación femenina" (haec consternatio muliebris). El Censor especuló que no conocía la razón que desencadenó dicha insubordinación, si se debía a consecuencia del azar o por instigación de los tribunos de la plebe. Ahora, lo que sí que dejó bien claro es que en caso de que accedieran a las pretensiones de las mujeres, los culpables serían los votantes ${ }^{97}$. La cuarta parte, extensa, se inicia con la descripción del sentimiento bochornoso sufrido a su llegada al foro tras hacerse camino entre un ejército de mujeres que se agolpaban en los alrededores (ante per medium agmen mulierum in forum perueni). Tras ello puntualizó que, si sus ancestros dispusieron una división espacial entre hombres y mujeres, no había necesidad de modificarla. Para ello apeló al aspecto religioso y en especial a la tradición, pues si se permitía que estas últimas fueran iguales que los varones, llegaría un momento en el que serían superiores. Las leyes se buscaban útiles para la mayoría, pero no hallaba razón alguna para lo sucedido ${ }^{98}$. La siguiente parte concierne a los males que había asumido la sociedad romana: la auaritia y la luxuria ${ }^{99}$. Para argumentarlos, expuso que uno de ellos era a consecuencia de la influencia de otras culturas, que provocó una alteración de las tradiciones romanas. La expansión territorial de Roma, especialmente tras la conquista de Grecia y Asia, desencadenó importantes males para la sociedad. Por otro lado, debido a la condición femenina, advirtió que de no existir esta ley que frenara sus deseos, por su codicia natural intentarían obtener un mayor

94. Liv., XXXIV, 2, 1-14; 3, 1-9; 4, 1-21.

95. Liv., XXXIV, 2, 1-3.

96. Liv., XXXIV, 2, 3-6.

97. Liv., XXXIV, 2, 6-8.

98. Liv., XXXIV, 2, 8-14; 3, 1-5.

99. En la traducción castellana ofrecida por José Antonio Villar Vida de 1993 en la colección de Gredos habla de codicia y despilfarro. Cf. Liv., XXXIV, 4, 2. 
número de bienes y nunca quedarían saciadas ${ }^{100}$. Finalmente terminó sentenciando que era mejor que se mantuviera la ley y para ello pedía la intercesión divina ${ }^{101}$.

Las palabras de Catón, tal y como afirmó Cantarella, no respondieron a un pensamiento particular y aislado, sino a un sentir mayoritario. Sin embargo, es cierto que este hecho fue algo inaudito, pues las mujeres no solo habían ocupado el espacio público, sino también se inmiscuyeron en cuestiones de carácter público y político ${ }^{102}$. De hecho, Livio, que recogió el testimonio del triunviro Lucio Valerio $^{103}$, matizó que éste comenzó su alegato recordando que las palabras del Censor más que una defensa de la ley, constituían una crítica a la actitud adoptada por las matronas. Además, en esta primera parte expuso que lo que reclamaban era lícito, pues la situación que se vivía no era calamitosa, ya que eran tiempos de paz y la República se mostraba restaurada y floreciente. Por otro lado, alegó que la visión catastrófica y única que pretendía demostrar el Censor, alegando que las mujeres siempre habían estado en el ámbito doméstico, no era del todo cierta. Desde el principio se dieron momentos en los que participaron activamente para defender el bien común y para ello animaba a que revisara su obra Orígenes ${ }^{104}$. Aquí debemos hacer una puntualización, pues hay un anacronismo en el relato. Sabemos que la obra fue redactada por Catón en su etapa madura, lo que nos indica que este pasaje fue añadido con posterioridad. Además, ambos plantean el problema desde diferentes ópticas, pues para el primero no era solo una reivindicación femenina para llevar un determinado atuendo, sino una crítica a la aptitud adoptada por las matronas. La violación del papel natural a las que estaban sometidas las mujeres y la transgresión de roles desencadenaría el desmoronamiento del sistema del que también se verían perjudicados los varones ${ }^{105}$.

La segunda parte del discurso de Valerio viene introducida por él mismo tras comentar que entraría en lo que al debate se refiere (uenio nunc ad id de quo agitur). Argumentó que estaba de acuerdo con que aquellas leyes basadas en la tradición no debían ser modificadas. Ahora bien, las creadas a consecuencia de una situación excepcional, como lo sucedido en este caso, eran caducas y tenían un tiempo determinado de aplicación. Las normas que eran adecuadas en tiempos de guerra tenían que ser eliminadas cuando la situación de paz modificara la realidad. Además, si antes de la promulgación de esta ley las matronas habían vivido con una moralidad intachable, ¿por qué la situación iba a cambiar? Los varones podían llevar la púrpura y no tenía sentido alguno que sus mujeres estuvieran privadas de poder lucir sus atuendos más característicos. Por otro lado, matizó que, de no

100. Liv., XXXIV, 4, 1-21.

101. Liv., XXXIV, 4, 21.

102. Cantarella, 1991: 39 .

103. Liv., XXXIV, 5, 1-13; 6, 1-18; 7, 1-15.

104. Liv., XXXIV, 5, 1-13.

105. Mas Torres, 2006: 412. 
dejarlas, también iría contra la tradición. Los ancestros dispusieron que debido a que no podían ejercer ninguna magistratura ni participar de la vida pública, los adornos y la elegancia constituía parte de su identidad ${ }^{106}$. En último lugar retomó las palabras de Catón cuando comparaba la situación que se estaba produciendo con la escisión de la plebe en el monte Aventino, de igual forma insistió que las mujeres nunca debían estar bajo la tutela del varón, pero tampoco había que tenerlas como si fueran esclavas ${ }^{107}$.

Se ha discutido sobre la autenticidad de las palabras pronunciadas por el autor de la obra Orígenes, algo que realmente tampoco es importante. Tal y como opinó Mastrorosa, más transcendental para el contenido histórico fue el razonamiento adoptado por Livio en la reconstrucción ofrecida del debate catoniano, así como los aspectos vinculantes con la consideración femenina de la época ${ }^{108}$. Aunque al respecto podemos pronunciarnos que, al igual que se ha demostrado que el discurso de Lucio Valerio fue modificado con posterioridad, donde se incluye la mención al trabajo de Catón, también la narración original pronunciada por este último pudo ser alterada. Más allá de lo estrictamente moral, no solo pudo ser entendida la ley como un deseo por recobrar la austeridad romana y costumbres ancestrales que tantos beneficios habían dado a la res publica, sino también, no hay que olvidar que el Estado se encontraba en una situación comprometida tras los costes ocasionados por la guerra. Por tanto, no era del todo correcto que mientras un gran número de personas se encontraban sin algún familiar y empobrecidos, la nobilitas rica y ostentosa mostrara su lujo por toda la ciudad ${ }^{109}$. Tampoco podemos olvidar la personalidad de Catón, fiel a las tradiciones y defensor de la uirtus romana, lo que le llevaría a convertirse en uno de los exponentes más importantes del conservadurismo de la época ${ }^{110}$.

Una situación que aparentemente no era transcendental o se suponía que no acarrearía demasiados problemas, se transformó en un conflicto social de gran calado. Un grupo heterogéneo pero unido en las reivindicaciones y que aparentemente estaba excluido de las decisiones políticas, consiguió que una ley fuera derogada con el apoyo unánime de las tribus ${ }^{111}$. De nada sirvieron las palabras pronunciadas por el Censor. De las noticias extraídas de Livio o Valerio Máximo se puede señalar el éxito de la unión que tuvieron las mujeres en aquella época ${ }^{112}$.

106. Liv., XXXIV, 6, 1-10.

107. Liv., XXXIV, 6, 11-15.

108. Mastrorosa, 2006: 591-592.

109. Clemente, 1981: 5; Casinos Mora, 2015: 234-235.

110. García Fernández, 2001: 304; García Fernández y Rodríguez Mayorgas, 2006: 402.

111. De hecho, después de ofrecer los dos discursos, el de Catón como el de Lucio Valerio, Livio finaliza diciendo que la afluencia de mujeres no cesó hasta llegar a desbordar los espacios públicos y finalmente fue derogada. Liv., XXXIV, 8, 1.3.

112. Bauman, 1992: 34; Ferrer Alcantud, 2017: 273. 
A lo que habría que añadir que si llegó a prosperar fue a consecuencia de que estuvo promovido por damas pertenecientes a los estratos sociales acomodados ${ }^{113}$. Por tanto, estamos ante un hito social en la Historia de Roma definido por Haury como "une anné de la femme" 114 .

\section{2.-El discurso de Hortensia. Un unicum en la Roma Antigua}

En los años finales de la República se sucedieron diversos cambios. La instauración del gobierno de Julio César finalizó con su asesinato en las idus de marzo del año 44 a.C. Tras dicho acontecimiento comenzó un período conflictivo en el que además de diferentes luchas de poder, el sistema de la República mostraba signos irreversibles de debilitamiento que finalizarían con la instauración del Imperio por un joven Octavio, que pronto se convertiría en el poderoso emperador Augusto. Antes de llegar a ese punto, en el año 42 a.C., una joven patricia, de nombre Hortensia, llegó a hablar en el foro, posiblemente en la Rostra Julia ${ }^{115}$. En el caso de la derogación de la lex Oppia hemos visto a mujeres que transformaron la realidad a través de la persuasión e influencia sobre los varones, ya que fueron ellos los que, en definitiva, tomaron la decisión de suprimir una ley gravosa para las mujeres ${ }^{116}$. El ejemplo de Hortensia fue diferente. Entendemos y sostenemos la afirmación realizada Cid López al considerar a esta última como un caso extraordinario entre las romanas, pues su voz rompió el silencio femenino y defendió sus intereses sin la necesidad de utilizar al varón como instrumento ${ }^{117}$. Para poder contextualizar el discurso tendríamos que remontarnos a la etapa del segundo triunvirato, con Augusto, Marco Antonio y Lépido como protagonistas.

A consecuencia de los conflictos bélicos, las arcas estatales estaban mermadas y una vez más, como ocurrió con el asedio de Veyes y con la Segunda Guerra Pública, se reclamaban sumas importantes de capital a las mujeres más poderosas

113. Cid López, 2010: 143.

114. Tomado del título de su trabajo. Cf. Haury, 1976: 427-436.

115. Ortuño Pérez, 2016: 385. Algunos autores han cuestionado la veracidad del pasaje. Cf. Pina Polo, 1989: 72: "También excepcional, incluso poco creíble, es la narración de Apiano del discurso que hizo desde la tribuna Hortensia, hija del famoso orador, en contra del ya mencionado edicto de los triunviros, en el año 43 a.C., por el que hasta mil cuatrocientas mujeres debían evaluar su riqueza. Tal vez es sólo una invención, y en todo caso el episodio es tan extraño que los triunviros ordenan rápidamente la expulsión de Hortensia y de las demás mujeres". Para ver las posturas a favor y en contra de la veracidad del relato, cf. Mcclintock, 2013: 185 nota 10.

116. Pina Polo, 1989: 72.

117. Cid López, 2015: 198. De hecho, cuando ella pronuncia el discurso su padre había fallecido. No está claro si Hortensia se llegó a casar con Q. Servilio Cepio, hijo adoptivo de Bruto. Cf. Mantzilas, 2016: 173. 
de la ciudad ${ }^{118}$. El embargo de bienes de los proscritos, tras la sanción del 28 de noviembre del año 43 a.C., en el que se condenaron a 130 senadores y 2.000 equites $^{119}$, no fueron suficientes para paliar el déficit económico que atravesaba el erario. El Estado se vio obligado a adoptar medidas fiscales contundentes ${ }^{120}$. Disposición extraordinaria que exigía a mil cuatrocientas de ellas a hacer una estima de sus propiedades y dependiendo de sus bienes, tenían que sufragar un tributo para satisfacer las demandas de los triunviros y de los gastos militares. Se establecieron penas para quienes ocultaran parte de su patrimonio o hicieran una evaluación falsa, dando recompensas a los delatores de dichas prácticas fraudulentas, independientemente de su condición social, fueran libres o esclavos ${ }^{121}$.

Más allá de lo interesante que resulta conocer las medidas adoptadas, tal y como afirmó Ortuño Pérez, el contenido del decreto es interesante, pues muestra la situación del sistema en relación con el control fiscal y financiero ${ }^{122}$. También revela el poder económico que las matronas de las clases sociales más altas tenían en esa época. Al igual que como el caso anterior de la lex Oppia, las mujeres intentaron actuar por la vía indirecta y para ello persuadieron a aquellas próximas al círculo de los triunviros. Fulvia rehusó hablar con ellas e intentaron entonces dialogar con Octavia, hermana de Octaviano, y con Julia, madre de Marco Antonio, que tampoco accedieron a los requerimientos de las matronas ${ }^{123}$. Por tanto, la única opción fue intervenir ellas mismas y exponer públicamente su descontento.

Hortensia era hija del orador Quinto Hortensio, su discurso estaba plagado de referencias a los problemas sucedidos durante el final de la República. Su condición social le permitió conocer a la perfección las dificultades que atravesaba la sociedad romana y tuvo la valentía de criticar y cuestionar la política desarrollada por los dirigentes de su época ${ }^{124}$. Debido a que era hija de un reconocido orador, poseía cualidades intelectuales y retóricas que le permitió abogar por una causa a la que los hombres se habían negado. Valerio Máximo narró que defendió a las mujeres ante los triunviros con una elocuencia idéntica a la de su padre, además de mostrar firmeza en sus palabras. Con ello su progenitor volvía a la vida en la persona de su hija ${ }^{125}$. Similares atributos fueron los ofrecidos por Quintiliano ${ }^{126}$. Para ello, a través de algunos casos particulares, el autor de Calahorra ilustró otros modelos

118. Cid López, 2010: 144.

119. Takacs, 2008: 21.

120. Según las estimaciones ofrecidas por Apiano, pese a vender las propiedades de los que fueron proscritos, se quedaron cortos en doscientos millones de dracmas. App. B. Civ., IV, 31.

121. App. B. Civ., IV, 32; Cenerini, 2009: 73; Ortuño Pérez, 2016: 375-376.

122. Ortuño Pérez, 2016: 378-379.

123. Takacs, 2008: 21; Cenerini, 2009: 73.

124. Cid López, 2015: 198; Strong, 2016: 72-73.

125. Val. Max., VIII, 3, 3.

126. Posiblemente, su formación procediera de su propio padre como ha expuesto Ortuño Pérez, 2015: 4; Ibid., 2016: 370. 
en los que la educación ofrecida por unos padres preocupados tuvo sus frutos en la formación de personalidades importantes para la Historia de Roma. Los primeros ejemplos fueron los hermanos Graco, cuyas cualidades se debieron al esmero de su madre Cornelia. Lelia de su padre Cayo; y, en último lugar, Hortensia ${ }^{127}$.

Interesante al respecto es que Quintiliano mencionó que el discurso pronunciado por la hija de Hortensio constituyó un ejemplo de erudición en oratoria, independientemente de su condición femenina. Sin embargo, pese a los elogios ofrecidos por las fuentes clásicas, únicamente Apiano fue el autor que reprodujo de manera íntegra la supuesta intervención ${ }^{128}$. La hija de Hortensio al principio se justificó de los motivos que le condujeron a ciertas matronas a elevar sus súplicas ante tan ilustre cámara. Explicando que habían recurrido a ellos debido a que fueron ultrajadas por Fulvia y que, tras la pérdida de sus padres, hijos, maridos y hermanos, se habían visto abocadas a solicitar todas juntas un restablecimiento de sus derechos, pues las medidas emprendidas iban contra las costumbres y su condición femenina. Con una actitud que puede ser calificada como desafiante, alegó que, si ellas no habían sido proscritas, tampoco tuvieron la oportunidad de ejercer magistraturas, ni realizar ninguna acción destructiva contra ellos, no comprendían el motivo de tal castigo ${ }^{129}$. No existía razón que justificara que parte de su patrimonio fuera a parar al Estado con el fin de sufragar una guerra de la que ellas no habían sido partícipes. Además, la última vez que contribuyeron para financiar un conflicto bélico fue cuando Roma estaba en peligro por culpa de los cartagineses, mientras que la situación actual era bien distinta. No consistía en asistir a una contienda contra un enemigo exterior, sino un conflicto entre iguales, no existiendo ningún precedente ni en tiempos de César, Cinna o Sila. Por otro lado, en el pasado a las mujeres se les pidieron joyas, elementos decorativos que no suponía un peligro para su estabilidad, y de manera voluntaria. Por el contrario, ahora se les estaba obligando, lo que ponía en peligro sus tierras, campos, dotes $\mathrm{y}$ casas, que en muchos casos eran sus fuentes de subsistencia ${ }^{130}$.

Las referencias están plagadas de estereotipos que nos permiten apuntar, aunque jamás podremos asegurarlo, que estamos ante un discurso reelaborado y artificial. Bien es cierto que conocemos o intuimos la erudición y formación que tuvo Hortensia, pero las referencias sociales y políticas que se plasman en su alegato nos hacen dudar que fueran pronunciadas por una persona que estaba al margen del sistema político. Sin contradecir la información transmitida por Apiano, también es cierto que era extraño que una mujer fuera capaz de hablar en el foro en una etapa tan temprana. Pero entonces, ¿qué sentido tendría que el

127. Quint. Inst., I, 1, 6.

128. App. B. Civ., IV, 32-34.

129. App. B Civ., IV, 32.

130. App. B. Civ., IV, 33. 
autor lo pusiera de manifiesto en su obra? Todas estas cuestiones son de difícil resolución. Posiblemente estemos ante la exageración de una realidad mutable en la que las mujeres se atrevieron a denunciar y defender aspectos que consideraban injuriosos. También es cierto que demostró tener conocimientos históricos cuando aludió a los enfrentamientos entre César y Pompeyo (77-44 a.C.), así como a las campañas anteriores de Mario (157-86 a.C.), Cinna (130-84 a.C.) o Sila (138-78 a.C.). La intención de comparar la actuación de los triunviros con la de los dictadores responde a un deseo de mostrarles que su actitud era peor todavía y por ello finalizó con una frase en tono sarcástico diciéndoles que si eran ellos los que afirmaban estar consolidando la República ${ }^{131}$.

El texto de Apiano termina con las consecuencias que trajo consigo dicho discurso. Provocó que se irritaran los triunviros no solo porque estás mujeres se negaban a obedecerles, sino también por la actitud mostrada por los hombres que permanecieron impasibles y callados mientras ellas estaban hablando en un lugar tan distinguido ${ }^{132}$. Se ordenó a los lictores a que las expulsaran, pero éstos desoyeron la orden de los magistrados al encontrarse con un gran tumulto en el exterior de la cámara. Finalmente se decidió que se pospusiera la sesión para el día siguiente. Se rebajó el número de mujeres que tenían que pagar tributo, se pasó de mil cuatrocientas a solo cuatrocientas ${ }^{133}$. Aunque no consiguió Hortensia su propósito, que era que ninguna de ellas tuviera que pagar, sí que se redujo el número, lo que demuestra que sus esfuerzos en cierta manera tuvieron un efecto positivo para sus intereses; pero, sin duda, con esta acción se demostró que una protesta orquesta de manera organizada podía conseguir resultados, aunque las precursoras fueran mujeres.

\section{4.-Conclusiones}

Tal y como dijo Cid López, pese a que desde la época monárquica se forjaron estereotipos en el que las mujeres estaban relegadas al ámbito doméstico y para ello se creó una serie de biografías para explicar su exclusión de los círculos políticos, en ocasiones excepcionales las mujeres debieron prestar ciertos servicios a la res publica. Ello implicaba salir de sus hogares y adentrarse en los espacios masculinos. Estas acciones en su mayoría estaban protagonizadas por féminas que pertenecían a los círculos aristocráticos ${ }^{134}$. Por tanto, además de la excepcionalidad que suponían dichos sucesos, habría que sumarle que no fue una práctica generalizada; sino que, tal y como se ha explicado en la introducción, aquellas de condición social baja o

131. App. B. Civ., IV, 33; Ortuño Pérez, 2016: 399.

132. App. B. Civ., IV, 34.

133. App. B. Civ., IV, 34.

134. Cid López, 2010: 125-127. 
esclavas no tuvieron la oportunidad de reivindicar sus anhelos ni restablecer sus derechos, si es que tenían. Esta misma idea también fue apuntada previamente por Pomeroy, quien matizó que, a partir del relato de Tito Livio, se pueden extraer noticias en las que distinguidas matronas resultaron determinantes en ciertos actos cruciales para la salvación del Estado ${ }^{135}$. Pese a que hay quienes han visto en el discurso de Hortensia y en los de las mujeres de la nobilitas reacciones inconformistas, en ningún momento abogaron por abandonar los preceptos marcados por los mores maiorum. Es más, en todos los relatos anteriormente comentados sus actuaciones iban encaminadas a una defensa de las normas y del restablecimiento del status quo. Virginia encarnó la pureza virginal, mientras que Lucrecia fue la perfecta y virtuosa esposa. Por último, Veturia fue la mujer madura que tuvo claro que la estabilidad estatal imperaba por encima de cualquier aspecto particular. No importa si estamos ante personajes reales o ficticios. Los valores que defendieron estas mujeres, como la honra familiar y la razón de estado, fueron los sentimientos que todas las matronas y mujeres en general tenían que alcanzar a lo largo de su vida. Ello explicaría que, aunque puedan parecer dispares los ejemplos por la cronología, los sentimientos y valores que se pretendieron transmitir fueron los mismos. Otra cuestión es la realidad que se vivió a finales de la República, en la que hemos podido comprobar cómo el discurso encorsetado y minado de que las mujeres no podían hablar o salir del ámbito doméstico no fue del todo cierto. $\mathrm{Su}$ posición económica y la educación adquirida fueron factores fundamentales que permitieron alzar la voz a algunas de ellas a pesar de la negativa de sus homónimos masculinos. La unión que consiguieron fue importante para alcanzar ciertos requerimientos, siendo uno de los aspectos más importantes de esta época crucial de la Historia de Roma previa a la instauración de la etapa imperial.

\section{5.-Bibliografia}

BAEZA ANGULO, Eulogio y BUONO, Valentina (2013a): "Contaminaciones entre la matrona ideal y la puella elegíaca". Emerita, 81-2: 263-293.

BAEZA ANGULO, Eulogio y BUONO, Valentina (2013b): "La solitudine domestica della matrone elegiache". Ágora, 15: 33-50.

BAUMAN, Richard A. (1992): Women and Politics in Ancient Rome. Londres-Nueva York, Routledge. BEARD, Mary (2017): Women \& Power. A Manifesto. Londres, Porfile Books.

BEARD, Mary (2018): Mujeres y poder. Un manifiesto. Barcelona, Crítica.

BERG, Ria (2002): "Wearing Wealth. Mundus Muliebris and Ornatus at Status Markers for Women in Imperial Rome”. En SETÄLÄ, Päivi et al. (eds.): Women, Wealth and Power in the Roman Empire, Roma, Institutum Romanum Finlandie, pp. 15-73.

BRAVO BOSCH, María José (2017): Mujeres y símbolos en la Roma republicana. Análisis jurídicohistórico de Lucrecia y Cornelia, Madrid, Dykinson.

135. Pomeroy, 1987: 199. 
CANTARELLA, Eva (1991): La mujer romana, Santiago de Compostela, Universidade de Santiago Compostela.

CASINOS MORA, Francisco Javier (2015): La restricción del lujo en la Roma republicana. El lujo indumentario. Madrid, Dykinson.

CENERINI, Francesca (2009): La donna romana. Modelli e realtà. Bolonia, Il Molino.

CENERINI, Francesca (2014): "Il ruolo delle donne nelle città alla fine dell'età repùbblicana: il caso di Mutina”. En CHIABÀ, Monica (ed.): Hoc quoque laboris praemium. Scritti in onore di Gino Bandelli, Trieste, Edizioni Università di Trieste, pp. 63-82.

CHIUSI, Tiziana J. (2010-2011): "La fama nell'ordinamento romano. I casi di Afrania e di Lucrezia", Storie delle donne, 6-7: 89-105.

CID LÓPEZ, Rosa María (2006): “Joan Scott y la historia de las mujeres en España. El caso de los estudios sobre la Antigüedad”. En BORDERÍAS, Cristina (ed.): Joan Scott y las políticas de la historia, Barcelona, Icaria: Asociación Española de Investigación de Historia de las Mujeres (AEIHM), pp. 61-94.

CID LÓPEZ, Rosa María (2007): “Imágenes y prácticas religiosas de la sumisión femenina en la Antigua Roma. El culto de "Juno Lucina" y la fiesta de "Matronalia". Studia histórica. H. ${ }^{a}$ antigua, 25: 357-372.

CID LÓPEZ, Rosa María (2009), "Madres para Roma. Las "castas" matronas y la res publica". En CID LÓPEZ, Rosa María (coor.): Madres y maternidades. Construcciones culturales en la civilización clásica, Oviedo, KRK, pp. 155-182.

CID LÓPEZ, Rosa María (2010): "Mujeres "poderosas” del Imperio romano en la historiografía moderna. Algunas notas críticas a las visiones de la Ilustración y su influencia”. En FORNIS, César et al., (eds.): Dialéctica histórica y compromiso social: homenaje a Domingo Plácido, vol. 2. Madrid, Libros Pórtico, pp. 685-702.

CID LÓPEZ, Rosa María (2011): "El discurso religioso y jurídico en la Roma Antigua. La matrona y las mujeres de la Roma antigua. Un estereotipo femenino a través de las imágenes religiosas y las normas legales". En HIDALGO RODRÍGUEZ, David, CUBAS MARTÍN, Noemí y MARTÍNEZ QUINTERO, María Esther (eds.): Mujeres en la historia, el arte y el cine. Discursos de género, variantes de contenidos y soportes: de la palabra al audiovisual, Salamanca, Ediciones Universidad de Salamanca, pp. 55-70.

CID LÓPEZ, Rosa María (2015): "El género y los estudios históricos sobre las mujeres de la Antigüedad. Reflexiones sobre los usos y los estudios históricos sobre las mujeres de la Antigüedad. Reflexiones sobre los usos y evolución de un concepto". Revista de Historiografia, 22-1: 25-49.

CID LÓPEZ, Rosa María (2017): "Las matronas y los agmina mulierum en la Roma antigua. Del matriotismo a la protesta”. En MARTÍNEZ LÓPEZ, Cándida y UBRIC RABANEDA, Purificación (eds.): Cartografias de género en las ciudades antiguas, Granada, Editorial Universidad de Granada, pp. 207-232.

CLEMENTE, Guido (1981): "Le leggi sul lusso e la società romana tra III e II secolo a.C.”. En GIARDINA, Andrea y SCHIAVONE, Aldo (eds.): Modelli etici, diritto e trasformazioni sociali. Società romana e produzione schiavista, vol. III, Roma-Bari, Edizioni Laterza, pp. 1-14.

CONESA NAVARRO, Pedro David (2016): "Estudios sobre mujeres de la Antigua Roma. Estado de la cuestión, problemas y progreso científico en un campo histórico consolidado". Minius, 24: 205-226.

CONESA NAVARRO, Pedro David, GONZÁLEZ FERNÁNDEZ, Rafael: "De salvajes a domesticadas: aproximación a un ensayo sobre la justificación de la condición femenina en el mundo romano", Revue des Etudes Anciennes, 117-1: 87-108.

CONESA NAVARRO, Pedro David y GONZÁLEZ FERNÁNDEZ, Rafael (2016): "Honesta Mors. Suicidas y muertes inducidas de mujeres de la antigua Roma”. En RODRÍGUEZ LÓPEZ, Rosalía y BRAVO BOSCH, María José (eds.): Mujeres en tiempos de Augusto: realidad social e imposición legal, Valencia, Tirant lo Blanch, pp. 587-609. 
CULHAM, Phyllis (1982): “The Lex Oppia”. Latomus, 41-4: 783-793.

CULHAM, Phyllis (1986): "Again, What Meaning Lies in Colour!", Zetschrift für Papyrologie und Epigraphik, 64: 235-245.

DE LUCE, Judith (2005): "Roman Myth", $C W, 98$ - 2: 202-205.

DIXON, Suzanne (1992): The Roman Family, Baltimore-Londres, Johns Hopkins University Press.

FELSON-RUBI, Nancy (1994): Reading Penelope. From Character to Poetics. Princeton-Nueva Jersey, University of Oklahoma Press.

FERRER ALCANTUD, Coré (2012): "Mujeres influyentes en la república romana: el ejercicio del poder femenino a través de las asociaciones religiosas". En Martín CLAVIJO, Milagro (ed.): Congreso Internacional de La Asociación Universitaria de Estudios de las Mujeres (AUDEM). Más igualdad. Redes para la igualdad, Sevilla, Arcibel Editores, pp. 259-270.

FERRER ALCANTUD, Coré (2014): "La mujer romana y el ejercicio del poder a través del control de las finanzas: El caso de Terencia, esposa de Cicerón". Potestas. Revista del Grupo Europeo de Investigación Histórica. Religión, Poder y Monarquía, 7: 6-7.

FERRER ALCANTUD, Coré (2017): Mujeres y politica en la antigua Roma: poder, identidad, roles e influencia en la res publica. Castellón, Universitat Jaume I (tesis doctoral).

FUENTES MORENO, Francisco (2009): “Lucrecia”. En POCIÑA PÉREZ, Andrés y GARCÍA GONZÁLEZ, Jesús María (eds.): En Grecia y Roma, III: mujeres reales y ficticias, Granada, Editorial Universidad de Granada, pp. 95-114.

GALLEGO FRANCO, Henar (2015): “Crónicas de una relación Ilícita. Mujeres, acción política e historiografía en Hispania tardoantigua”. En DOMÍNUEZ ARRANZ, Almudena y MARINA SÁEZ, Rosa María (eds.): Género y enseñanza de la Historia. Silencios y ausencias en la construcción del pasado, Madrid, Sílex, pp. 315-343.

GARCÍA FERNÁNDEZ, Estela (2001): "Doctrina transmarina: la recepción de la filosofía griega en la Roma republicana”. En VEGA REÑÓN, Luis, RADA GARCÍA, Eloy y MAS TORRES, Salvador (eds.), Del pensar y su memoria. Ensayos en homenaje al profesor Emilio Lledó, Madrid, UNED. Universidad de Educación a Distancia, pp. 299-312.

GARCÍA FERNÁNDEZ, Estela y RODRÍGUEZ MAYORGAS, Ana (2006): “Tradición griega e identidad romana: la reflexión sobre los orígenes de Roma”. En PLÁCIDO, Domingo et al. (eds.): La construcción ideológica de la ciudadanía. Identidades culturales y sociedad en el mundo griego antiguo, Madrid, Editorial Complutense, pp. 395-406.

GARCÍA JURADO, Francisco (2011): "Matronas y meretrices en la comedia latina. Los discursos en conflicto". En LÓPEZ GREGORIS, Rosario y UNCETA GÓMEZ, Luis (eds.): Ideas de mujer. Facetas de lo femenino en la Antigüedad, Alicante, Universitat d'Alacant-Centro de Estudios de la Mujer, pp. 171-184.

GIROD, Virginie (2017): Les Femmes et le sexe dans la Rome Antique. París, Tallandier.

GONZÁLEZ SUAREZ, Amalia (1999): La concepción de lo femenino en la filosofía de Platón. Madrid, Clásicas.

HAURY, Auguste (1976): “Une “année de la femme” à Rome, 195 avant J.-C.?”. En L'Italie préromaine et la Rome républicaine. Mélanges offerts à J. Heurgon, vol. 2, Roma, École Française de Rome, pp. 427-436.

HEMELRIJK, Emily A. (1999): Matrona Docta. Educated women in the Roman elite from Cornelia to Julia Domna. Londres-Nueva York, Routledge.

KÜHNE, Viviana (2013): "La Lex Oppia Sumptuaria y el control sobre las mujeres”. En RODRÍGUEZ LÓPEZ, Rosalía y BRAVO BOSCH, María José (eds.): Mulier. Algunas Historias e Instituciones de Derecho Romano, Madrid, Dykinson, pp. 37-52.

LÓPEZ HUGUET, María Luisa: "Consideraciones generales sobre los conceptos de patria potestas, filius-, pater-, y materfamilias: una aproximación al estudio de la familia romana", Redur, 4: 193-213. 
LÓPEZ LÓPEZ, Aurora (1992): "Hortensia, primera oradora romana”, Florentia iliberritana, 3 : 317-332.

MANTZILAS, Dimitros (2016): "Female Domestic Financial Managers. Turia, Murdia, and Hortensia”. En BERG, Ria (ed.): The Material Sides of Marriage. Women and Domestic Economies in Antiquity, Roma, Institutum Romanum Finlandiae, pp. 169-179.

MANZO, Beatrice (2016): "La parola alle matrone. Interventi femminili in sedi pubbliche nell'età tardo repubblicana”. En CENERINI, Francesca y ROHR VIO, Francesca (eds.): Matronae in domo et in re publica agentes. Spazi e occasioni dell'azione femminile nel mondo romano tra tarda repubblica e primo impero. Atti del Convegno di Venezia 16-17 ottobre 2014, Trieste, Edizioni Università di Trieste, pp. 121-136.

MAS TORRES, Salvador (2006): “Catón el Censor y la invención de Grecia”. En PLÁCIDO, Domingo et al. (eds.): La construcción ideológica de la ciudadanía. Identidades culturales y sociedad en el mundo griego antiguo, Madrid, Editorial Complutense, pp. 407-422.

MASTROROSA, Ida Gilda (2006): "Speeches por and contra Women in Livy 34, 1-7: Catonian Legalism and Gendered Debates". Latomus, 65-3: 590-611.

MCCLINTOCK, Aglaia (2013): “The lex Voconia and Cornelia's Jewels”. RIDA, 60:183-200.

MIRÓN PÉREZ, María Dolores (2010): "Mujeres y poder en la Antigüedad Clásica: Historia y teoría feminista". Saldvie: Estudios de prehistoria y arqueología, 10: 113-125.

MOLAS FONT, Maria Dolors (2009): "La maternidad usurpada en las leyendas sobre los orígenes de Roma”. En CID LÓPEZ, Rosa María (coor.): Madres y maternidades. Construcciones culturales en la civilización clásica, Oviedo, KRK, pp. 138-150.

NOGALES BASARRATE, Trinidad (2017): "Moda romana: símbolo de estatus y actividad vital en una sociedad multicultural". Vinculos de Historia, 6: 40-70.

ORIA SEGURA, Mercedes (2016): "Matronas y madres: la creación de una imagen social". En MARCO SIMÓN, Francisco, PINA POLO, Francisco y REMESAL RODRÍGUEZ, José (eds.): Autorretratos: La creación de la imagen personal en la Antigüedad, Barcelona, pp. 159-174.

ORTUÑO PÉREZ, María Engracia (2015): "La oratoria femenina y la fiscalidad en la segunda mitad del siglo i a.C.: un caso singular”. Revista General de Derecho Romano, 25: 1-30.

ORTUÑO PÉREZ, María Engracia (2016): "Hortensia. Su discurso contra la imposición fiscal femenina”. En RODRÍGUEZ LÓPEZ, Rosalía y BRAVO BOSCH, María José (eds.): Mujeres en tiempos de Augusto. Realidad social e imposición legal, Valencia, Tirant lo Blanch, pp. 367-400.

PEDREGAL RODRÍGUEZ, María Amparo (2011): "La historia de las mujeres y la historia antigua en España: Balance historiográfico (1980-2008)". Dialogues d'histoire ancienne, 37-2: 119-160.

PINA POLO, Francisco (1989): Las contiones civiles y militares en Roma. Zaragoza, Ediciones Universidad de Zaragoza.

POMEROY, Sarah B. (1987): Diosas, rameras, esposas y esclavas. Mujeres en la Antigüedad Clásica, Barcelona, Akal.

REBOREDA MORILLO, Susana (2009): "Penélope: la maternidad en el caos". En CID LÓPEZ, Rosa María (coor.): Madres y maternidades. Construcciones culturales en la civilización clásica. Oviedo, KRK, pp. 59-60.

REDONDO-MOYANO, Elena (2016): "El encuentro de Valeria y Coriolano (D. H. Antiquitates Romanae 8, 44-53)". Studia Philologica Valentina, 18-15: 335-342.

STRONG, Anise K. (2016): Prostitutes and Matrons in the Roman World. Nueva York, Cambridge University Press.

TAKÁCS, Sarolta A. (2008): Vestal Virgins, Sibyls, and Matrons: Women in Roman Religion. Texas, University of Texas Press.

VALENTINI, Alessandra (2012): Matronae tra novitas e mos maiorum. Spazi e modalità dell'azione pubblica femminile nella Roma medio repubblicana. Venecia, Istituto Veneto di Scienze, Lettere ed Arti. 